\title{
Synthesis of Some New Substituted 1,3,4-Oxadiazole and
}

\section{1,3,4-Thiadiazole Derivatives}

\author{
Amena.A. Ahmed \\ Department of Chemistry/College of Education/University of Mosul

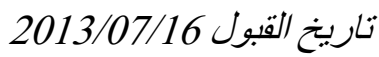 \\ 2013/05/21 تاريخ الاستلام
}

\section{الخلاصة}

يتضمن هذا البحث تحضير مركبات حلقيه غير متجانسة خماسية، وذلك باسستخدام حامض 2-(8-كلورو نفثويل) البنزويك (1) كمادة اساسية الذي حضر من مفاعلة 1- كلورو نفثالين مع انهيدريد الفثاليك بوجود كلوريد الالمنيوم الامائي ثم تحويله الى الاستر المقابل (2) ثم الى الهيدرازيد من خلال تفاعله مع الهيدرازين المائي في الايثانول (3) وبعدها تحويل الهيدرازيد (3) الى مشتقات الترايازول. كما تم مفاعله الهيدرازيد (3) مع ثايوسيانات الامونيوم بوجود حامض الهيدروكلوريك المركز للحصول على معوض الثايوسيمكاربازيد (7) وحول الاخير الى الثايادايازول (8) عند استخدام الوسط الحامضي اما عند استخدام كواشف الاكسدة فقد تم الحصول على الاوكسادايازول (9) وعند معاملته مع البنزلديهايد تم الحصول على قواعد شيف التي تمت حولقتها الى الثايازولدين (11) باستخدام حامض الثايوكلايكوليك. كما تم تحويل المركب (1) الى كلوريد الحامض بمفاعلته مع كلوريد الثايونيل ثم تحويله الى الاستر المعوض (13) بمفاعلته مع كلايسينات الاثيل وتحويل (13) الى الهيدرازيد (14) بمفاعلته مع الهيدرازين المائي في الايثانول، وقد حول المركب (14) الى هيدرازون ثم الى مشتقات الاوكسادايازول . كما تمت حولقت الهيدرازون الى الثايازولدين باستخدام حامض الثايوكلايكوليك. وقد تم الحصول على مشتقات الاوكسادايازول (19) من مفاعله المركب (1) مع اوكسي كلوريد الفففور بوجود الهيدرازيد (18) الذي تم الحصول عليه من مفاعله كلايسينات الاثيل مع الهيدرازين المائي بوجود الايثانول. تم تشخيص تراكيب المركبات المحضرة باستخدام الطرق الطيفية والفيزياوية. 


\begin{abstract}
In this paper the synthesis of five membered ring heterocyclic compounds was achieved, 2-(8-chloro naphtoyl) benzoic acid (1) was used as starting material which was prepared from the condensation of 1- chloro naphthalene with phthalic anhydride in presence of anhydrous aluminum chloride, the acid was then esterified to the corresponding ethyl ester(2). The ester(2) was converted to the corresponding hydrazide(3) then cyclized into substituted 1,2,4 triazole. The hydrazice(3) was treated with ammonium thiocyanate in presence of concentrated hydrochloric acid to give substituted thiosemicarbazide(7) which was converted to 1,3,4thiadiazole (8) in acidic medium. While in oxidation with $\mathrm{HgO}$ the product was oxadiazole(9). This was converted to a Schiff base(10) followed by cyclization to the corresponding thiazolidine derivative(11). Compound (1) was also converted to ethyl ester (13) via acid chloride (12), which was treated with hydrazine hydrate in ethanol to give the corresponding hydrazide (14) which converted to oxadiazole(16) and thiazolidine(17). Compound (19) was synthesized from compound (1) by its reaction with hydrazide (18) then it was cyclized by phosphorus oxychloride. The structures of synthesis compound were confirmed by spectral and physical methods.
\end{abstract}

\title{
Introduction
}

Heterocyclic compounds containing five-membered oxadiazole nucleus posses adiversity of useful biological effect 1,3,4-oxadiazole and 3 -aroylpropionicacid moieties are important because of there versatile biological action [1] In particular, Compound bearing the 1,34-oxadiazole nucleus are known to have unique antioedema and anti-inflammatory activities [1-3]. Differently substituted oxadiazole moieties have also been found to have other interesting activities such as analgesic [2,3] antimicrobial[4], antitubercular[5], anticonvulsant[6] and anti-hepatitis B viral activities[7]. 1,2,4 triazole or 1,3,4-thiadiazole moieties represent interesting class of compound possessing awide spectrum of biological activities such as anti-inflammotry activities[8], antivira1[9] antimicrobial[10,11], antitumor[12] antifungal and anti-bacterial[13].The compound5-(4-cyclopropyp-5-((3-fluorobenzyl)thio)-4h-1,2,4-triazol-3yl-4-methyl-1,2,3-thiadiazole was found to have fungicidal activity [14]. 


\section{Experimental}

All chemicals were purchased from Fluka and BDH chemical Ltd. The melting points were measured on an Electro thermal 9300 Engineering Ltd. and are uncorrected.IR spectrum were recorded on Infrared spectrophotometer Model Tensor 27, Bruker Company, Germany, using $\mathrm{KBr}$ discs.

\section{2-(8-chloro-1-naphthoyl benzoic $\operatorname{acid}(1)^{(16)}$}

A mixture of phthalic anhydride $(0.1$ mol, $14.8 \mathrm{~g})$ in 1chloronaphthalene $(50 \mathrm{ml})$, anhydrous aluminium chloride $(0.1 \mathrm{~mol}, 13.2 \mathrm{~g})$ was added in small protions over aperiod of $(2 \mathrm{~h})$ under stirring. The reaction mixture was then refluxed for two hours and after completion of the reaction, the 1-chloronaphthalene was removed by steam distillation. It was purified by dissolving in sodium hydroxide solution, Filtering followed addition of hydrochloric acid. The solid so obtained was filtered washed with cold water, dried and crystallized from methanol to give a solid product, which gave effervescence with sodium bicarbonate solution to afford compound (1) m.p $\left(210 \mathrm{C}^{0}\right),(85 \%$ yield), Orange in color.

\section{Ethyl-2-(8-chloro-1-naphthoyl) henzoate (2) ${ }^{(17)}$}

(0.01 mole, 3.18g) of compound (1) was reflux with absolute ethanol $(50 \mathrm{ml})$ and concentrated sulfuric acid $(5 \mathrm{ml})$ for $(6 \mathrm{hr})$, cooled the mixture was poured on to $(5 \%)$ ice cooled sodium carbonate solution, a white solid which separated. Compound it was recrystallized from ethanol to afford compound (2) .m.p(1130C $)$, (80\% yield), as Yellow.

\section{Acid Hydrazide (General Procedure)(3) ${ }^{(18)}$}

Hydrazine hydrate $(0.01$ mole) was added to a solution of compound $(2,13$,ethylglycine) $(0.01 \mathrm{~mole})$ in ethanol $(10 \mathrm{ml})$. The reaction mixture was heated under reflux for $(6 \mathrm{hrs})$, the mixture was concentrated in vacuum to give solid product of compound (3), m.p $\left(302 \mathrm{C}^{\circ}\right)$. $(75 \%$ yield) in White color, while compound (14) was obtained as an oil with (63\% yield). Compound (18) was also obtained as oil with as (83\% yield).

\section{Potassium2-8-chloro-l-naphthoyl) phyenyl dithiocarbazate (4) ${ }^{(19)}$}

A solution of $(0.015$ mole, $0.84 \mathrm{~g})$ of potassium hydroxide, $(50 \mathrm{ml})$ of absolute ethanol, and $(0.01$ mole, $3.32 \mathrm{~g})$ of hydrazide (3), was mixed thoroughly and $(0.015 \mathrm{~mole})$ of carbon disulfide was then added.The mixture was stirred at room temperature for two hours. oily product was obtained. (85\% yield), as pale Brown. 
4-amino-5-

thiol(5) ${ }^{(19)}$

(2-(8chloro-1-naphthoyl)phenyl-4h-1,2,4,-triazole-3-

To a suspension of $(0.02$ mole, $8.92 \mathrm{~g})$ of potassium dithiocarbazate (4), Hydrazine hydrate $(40 \mathrm{ml})$ and water $(4 \mathrm{ml})$ were added the final mixture was refluxed with stirring for $(1 \mathrm{hr})$ until the evolution of hydrogen sulphide had ceased, The mixture was diluted with water $(100 \mathrm{ml})$ and acidified with hydrochloric acid. The solution was filtered and recrystallized from ethanol- water gave a Brown compound. m.p. $\left(178 \mathrm{C}^{\circ}\right.$ ), (55\% yield).

\section{3,5- (2-(8-chloro-1-naphthoyl) phenyl-4- amino-1,2,4-triazole (6) ${ }^{(20)}$}

Acid hydrazide (3) (0.02 mole,6.64g) was heated at (130-150) $\mathrm{C}^{\circ}$ for $(1 \mathrm{hr})$, water $(50 \mathrm{ml})$ was added. The reaction mixture was refluxed for (15)minutes. The solvent was evaporated under reduced pressure to give oily product.(61\% yield), as Green compound.

\section{2-(8-chloro-1-naphthoy) phenyl thiosemicarbazide(7) ${ }^{(21)}$}

Amixture of hydrazide (3) (0.01 mole,3.32g) ammonium thiocyanate $(0.03 \mathrm{ml}, 2.28 \mathrm{~g})$ and concentrated hydrochloric acid $(4 \mathrm{ml})$ in ethanol $(50 \mathrm{ml})$ was refluxed for $(2 \mathrm{hr})$. The solvent was evaporated under reduced pressure to give Orange solid product. (71\% yield),m.p. $\left(172 \mathrm{C}^{0}\right)$.

\section{2-(2-(8-chloro-1-naphthoyl) phenyl -5-amino 1,3,4 -thiadiazole $(8)^{(22)}$}

Substituted thiosemicarbazide $(7)(0.01 \mathrm{~mol}, 3.91 \mathrm{~g})$ was dissolved in concentrated sulphuric acid $(1 \mathrm{ml})$ and stirred at room temperature for $(1$ $\mathrm{hr})$, then cold water $(25 \mathrm{ml})$ was added. The precipitate was filtered, dried and recrystallized from ethanol. m.p. $\left(120 \mathrm{C}^{0}\right),(4 \%$ yield $)$, as pale Green compound

\section{2(2-(8-chloro-1-naphthoyl) phenyl-5-1,3,4-Oxadiazole(9) ${ }^{(23)}$}

A mixture of substituted thiosemicarbazide(7) (0.001 mole, $0.391 \mathrm{~g})$ in methanol $(25 \mathrm{ml})$ and mercuric oxide $(0.001$ mole, $0.24 \mathrm{~g})$ was refluxed for four hours. The mixture was filtered while hot, the solvent then evaporated under reduced pressure to give solid product, recrystallised from ethanol. m.p. $\left(288 \mathrm{C}^{0}\right),(62 \%$ yield $)$, as pale White compound 


\section{2(2-(8-chloro-1-naphthoyl) phenyl-5amino1,3,4-Oxadiazole(10) ${ }^{(24)}$}

A mixture of compound (9) $(0.01 \mathrm{~mole}, 3.5 \mathrm{~g})$, benzaldehyde $(0.01 \mathrm{~mole}, 1.06 \mathrm{~g})$ and a drop of glacial acetic acid was refluxed in methanol $(30 \mathrm{ml})$ for $(6 \mathrm{hrs})$. The solvent was distilled of at reduced pressure and a solid separated out and was filtered, dried and recrystallized from ethanol. The compound has m.p. $\left(243 \mathrm{C}^{0}\right)$ ( $75 \%$ yield), as Yellow compound.

\section{N-[2-(2-(8-chloro-1-naphthoyl)phenyl)1,3,4-oxadiazole5-yl]-2-phenyl thiazolidine-5-one $(11)^{(25)}$}

A mixture of (0.004 mol,1.75 g) of compound (10) and thioglycolic acid $(0.02 \mathrm{~mol}, 0.38 \mathrm{~g})$ and (1) gm Zinc chloride anhydrous in (30) $\mathrm{ml}$ from methanol. The mixture was stirred for $(2 \mathrm{hr}$ and refluxed for further $(10 \mathrm{hr})$, concentrated under reduced pressure. The product obtained was yellow oil in $(62 \%$ yield).

\section{2-8-chloro-1-naphthol benzoyl chloride (12) $)^{(26)}$}

The $(0.01$ mole, $3.18 \mathrm{~g})$ of compound (1) was added to $(0.11$ mole, $9.53 \mathrm{ml})$ of thionyl chloride. The mixture was refluxed with stirring for (1 hr). The mixture was concentrated in vacuum. The solid product was crystallize from ether. m.p.(280d), (86\% yield), as Brown compound

\section{Etheyl-2-(8-chloro-1-naphthoy) benzoyl glycinate (13) ${ }^{(26)}$}

$(0,01 \mathrm{~mole}, 3.36 \mathrm{~g})$ of compound (12) dissolved in $(50 \mathrm{ml})$ dry T.H.F and $(0.02 \mathrm{~mole}, 2.06 \mathrm{~g})$ of ethyl glaycin was gradually added and refluxed for( $1 \mathrm{hr}$ ) in water bath. The mixture was concentrated in vacuum. To the final solution sodium bicarbonate $(5 \%)$ was then added to afford compound (13) As Yellow product m.p. $\left(170 \mathrm{C}^{\circ}\right),(79 \%$ yield).

Schiffs base (15) ${ }^{(27)}$

Hydrzide (14) (0.01 mole) in $(50 \mathrm{ml})$ ethanol was added to benzaldehyde ( $0.01 \mathrm{~mole} / 25 \mathrm{ml}$ ethanol). The mixture was reflux for $(2 \mathrm{hr})$ then cooled. The solid product was filtered and recrystallized from ethanol. m.p. $\left(90 \mathrm{C}^{0}\right),(73 \%$ yield), as pale Yellow product.

2-(2-(8-chloro-1-naphthoyl)phenyl)phenyl-5-yl 1,3,4-oxadiazole (16) (28)

Compound (15) (0.01 mole,4.47g) added to $(40 \mathrm{ml})$ acetic acid was and $(0.01$ mole) of lead oxide, the mixture was stirred at room temperature for one hour, then the mixture was diluted with $(100 \mathrm{ml})$ ice-water. The 
solid product was filtered and recrystallized from ethanol, m.p $\left(235 \mathrm{C}^{0}\right)$ (51\% yield), as Brown compound.

\section{2-phenyl-3- (2-8-chloro-1-naphthoyl) phenyl thiazolidine-4-one(17) ${ }^{(25)}$}

Amixture of $(0.004 \mathrm{~mol}, 1.908 \mathrm{~g})$ of compound(15) and thioglycolic acid $(0.002 \mathrm{~mol}, 0.38 \mathrm{~g})$ and $(1) \mathrm{gm}$ Zinc chloride anhydrous in $(30 \mathrm{ml})$ from methanol. The mixture was stirred for ( $2 \mathrm{hr})$ and refluxed for (10hrs). The mixture was then concentrated in vacuum. The solid product was crystallized from ethanol to give a Green compound has $\mathrm{m}$ p. $\left(197 \mathrm{C}^{\circ}\right)$, ( $86 \%$ yield).

\section{2-(2-8-chloro-1-naphtholy) phenyl-5-aminomethyl 1,3,4 -oxadiazole (19) ${ }^{(16)}$}

acid hydrazide (18) (0.01 mole, $0.89 \mathrm{~g}$ ) was dissolved in phosphorous oxychloride $(5 \mathrm{ml})$ and $(0.01 \mathrm{~mole}, 3.18 \mathrm{~g})$ of compound was added. The reaction mixture, was refluxed for ( $5 \mathrm{hrs})$, cooled to room to and pourcd on to crushed ice. On neutralization of the mixture with sodium bicarbonate solution (20\%), a solid product separated out and was filtered, washed with water and dried. It was crystallized from methanol. To give Brown compound with, m.p $\left(315 \mathrm{C}^{\circ}\right),(45 \%$ yield $)$.

\section{Results and Discussion}

In our study, the synthesis of some substituted 1,3,4oxadiazole,1,3,4-thiadiazoles and 1,2,4-triazoles was reported (scheme-1), chloro naphthalene was treated with phthalic anhydride to give carboxylic acid(1), The IR spectra of compound (1) showed the following absorption bands $\mathrm{KBr} \mathrm{cm}{ }^{-1} 3443(\mathrm{O}-\mathrm{H}), 2971.2875(\mathrm{C}-\mathrm{H}$, alphiatic), $3006(\mathrm{C}-\mathrm{H}$, aromatic), 1707( $\mathrm{C}=\mathrm{O})$ acid, $1653(\mathrm{C}=\mathrm{O})$ ketonic carbonyl and $1071(\mathrm{C}-\mathrm{O})$, 1558-1540 $(\mathrm{C}=\mathrm{C}$, aromatic). compound (1) was treated with ethanol absolute to give ester (2), The IR spectra of compound (2) showed the following absorption bands $\mathrm{KBr} \mathrm{cm}^{-1} 2924,2853$ (C-H, alphiatic), 3010(C$\mathrm{H}$, aromatic $), 1731(\mathrm{C}=\mathrm{O}), 1636(\mathrm{C}=\mathrm{O})$ ketonic carbonyl, 1505$1459(\mathrm{C}=\mathrm{C}$, aromatic), $1139(\mathrm{C}-\mathrm{O})$. compound(2) was converted in to the acid hydrazide (3) by their reaction with hydrazine hydrate in absolute ethanol.

The IR spectra of compound (3) showed the following absorption bands $\mathrm{KBr} \mathrm{cm}^{-1}$

$(\mathrm{N}-\mathrm{H}), 1630(\mathrm{C}=\mathrm{O}), \quad 1579-1506(\mathrm{C}=\mathrm{C}$, aromatic).compound (4) was prepared by reaction of compound(3)with carbon disulfide in ethanolic potassium hydroxide. The IR spectra of compound (4) showed the following absorption bands $\mathrm{KBr} \mathrm{cm}^{-1}$. 3464(N-H), $1606(\mathrm{C}=\mathrm{O}), 3060(\mathrm{C}-$ $\mathrm{H}$, aromatic). $(\mathrm{C}=\mathrm{C}$, aromatic) $1590-1446,1286(\mathrm{C}=\mathrm{S})$. Compound (5) was 
obtained from the reaction of (4) with hydrazine hydrate under reflux in solution. The IR spectra of compound (5) showed the following absorption bands $\mathrm{KBr} \mathrm{cm}^{-1} 3325(\mathrm{~N}-\mathrm{H}), 1614(\mathrm{C}=\mathrm{N}), 1338,1242,1095(\mathrm{~N}-\mathrm{C}=\mathrm{S})$. acid hydrazide (3) was converted to triazole (6) when heated at $(130-150) \mathrm{C}^{0}$ for one hour. The IR spectra of compound (6) showed the following absorption

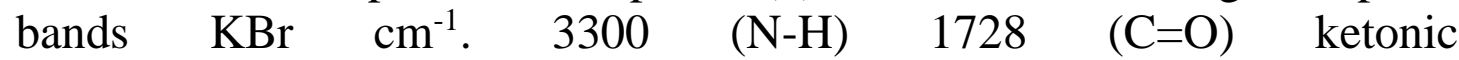
carbonyl, 1649 $(\mathrm{C}=\mathrm{O}), 1601(\mathrm{C}=\mathrm{N})$, the observation bands were found to be similar to the published in one similar compounds[20]. The reaction of acid hydrazide(3) with ammonium thiocyanate in acidic medium afforded substituted thiosemicarbzide(7) which cyclized to 1,3,4- thiadiazole (8) by sulphuric acid. The IR spectra of compound (7) showed the following absorption bands $\mathrm{KBr} \mathrm{cm}^{-1} .3421(\mathrm{~N}-\mathrm{H}), 1620(\mathrm{C}=\mathrm{O}, 1743(\mathrm{C}=\mathrm{O}), 1095$ $(\mathrm{C}=\mathrm{S})$, the observation bands were found to be similar to the published in one similar compounds [21]. where as compound (8) the absorption bands for $(\mathrm{N}-\mathrm{H}) 3467,(\mathrm{C}=\mathrm{O}) 1641,1603(\mathrm{C}=\mathrm{N}), 1462(\mathrm{C}=\mathrm{C}$ aromatic $)$, the observation bands were found to be similar to the published in one similar compounds [29]. compound (7) treatment. with mercuric oxide give compound (9). The IR spectra of compound (9) showed the following absorption bands $\mathrm{KBr} \mathrm{cm}^{-1} 3109(\mathrm{~N}-\mathrm{H}, 1630(\mathrm{C}=\mathrm{N}), 1522(\mathrm{C}=\mathrm{C})$, aromatic), the observation bands were found to be similar to the published in one similar compounds[24].The compound (9) reacted with benzaldehyd to give Schiff's base(10). The IR spectra of compound (10) showed the following absorption bands $\mathrm{KBr} \mathrm{cm}^{-1} .1624(\mathrm{C}=\mathrm{N}), 1446(\mathrm{C}=\mathrm{C}$, aromatic), $1160(\mathrm{C}-\mathrm{O}-\mathrm{C})$, the observation bands were found to be similar to the published in one similar compounds [24]. compound (10) was converted to compound (11) reacted with thioglycolic acid, The IR spectra of compound (11)showed the following absorption bands $\mathrm{KBr} \mathrm{cm}^{-1} 1688$ $(\mathrm{C}=\mathrm{O}), 1468-1402(\mathrm{C}=\mathrm{C}$, aromatic), 2983-2937 (C-H, alphiatic), 3140(C$\mathrm{H}$, aromatic), the observation bands were found to be similar to the published in one similar compounds [25], Compound(1) was converted in to acid chloride(12) by their reaction with thionyl chloride. The IR spectra of compound (12) showed the following absorption bands $\mathrm{KBr} \mathrm{cm}^{-1}$ 3058 $(\mathrm{C}-\mathrm{H}, \quad$ aromatic $), 1619(\mathrm{C}=0), \quad 1727(\mathrm{C}=\mathrm{O}), 1594-1567 \quad(\mathrm{C}=\mathrm{C}$, aromatic), the compound (12) treated with ethyl glycin to give ester (13), The IR spectra of compound (13) showed the following absorption bands $\mathrm{KBr} \quad \mathrm{cm}^{-1} \quad 3462(\mathrm{~N}-\mathrm{H}), \quad 1731(\mathrm{C}=\mathrm{O}), \quad 1636(\mathrm{C}=\mathrm{O}), 1505-1459(\mathrm{C}=\mathrm{C}$, aromatic), 1139-1071(C-O), 2853-2924(C-H,alphatic),3010(C$\mathrm{H}$,aromatic), the compound(13) was converted in to the acid hydrazide (14) by their reaction with hydrazine hydrate in ethanol absloute). The IR spectra of compund (14) showed the following absorption bands $\mathrm{KBr} \mathrm{cm}^{-1}$ $3348(\mathrm{~N}-\mathrm{H}), 2927$ (C-H lphatic) 1618(C=O),1473(C= C, aromatic), 1191(C-O), the reaction of acid hydrazide with benzaldehyde give hydrazone (15). The IR spectra of compound (15) showed the following 
absorption bands $\mathrm{KBr} \mathrm{cm}{ }^{-1} 3120(\mathrm{~N}-\mathrm{H}), 1624(\mathrm{C}=\mathrm{O}, 1600-1574(\mathrm{C}=\mathrm{N})$, compound (15) which cyclized to 1,3,4 oxadiazole (16) by lead oxide. The IR spectra of compound (16) showed the following absorption bands $\mathrm{KBr}$ $\mathrm{cm}^{-1} 3109$

$(\mathrm{C}-\quad \mathrm{H}), 1630(\mathrm{C}=\mathrm{N}), 1522(\mathrm{C}=\mathrm{C}$, aromatic $) 3355(\mathrm{~N}-\mathrm{H})$. Treatment of compound (15) with $\mathrm{ZnCl} 2$ give substituted thiazolidine(17). The IR spectra of compound (17) showed the following absorption bands $\mathrm{KBr} \mathrm{cm}^{-1}$ show absorption at 1699,1655 for $(\mathrm{C}=\mathrm{O}), 2850 \mathrm{~cm}^{-1}$ for $(\mathrm{C}-\mathrm{H}$, alphatic $)$, the observation bands were found to be similar to the published in one similar compounds [25]. The compound (18) synthesized from ethyl glycin and hydrazine to give acid hydrazide(18) and the last one was react with compound(1) in phosphorous oxychloride to give (19). The IR spectra of compound (18) showed the following absorption bands $\mathrm{KBr} \mathrm{cm}^{-1} .3467(\mathrm{~N}$ -H).2954-2810 (C- H,alphatic), 1641(C =O), The IR spectra of compound (19) showed the following absorption bands $\mathrm{KBr} \mathrm{cm}{ }^{-1}, 1732(\mathrm{C}=$ O), 1633(C=N) 1495(C= C,aromatic), 3345(N-H), 3437(N-H), 3153(C-H, aromatic $1645(\mathrm{C}=\mathrm{N}), 1402(\mathrm{C}=\mathrm{C}$, aromatic $)$, the observation bands were found to be similar to the published in one similar compounds [16]. It is worth notily here that the presence of ketonic carbonyl group in compound 3,14 and18 was checked by 2,4-Dinitro phenyl hydrazine which gives positive test.

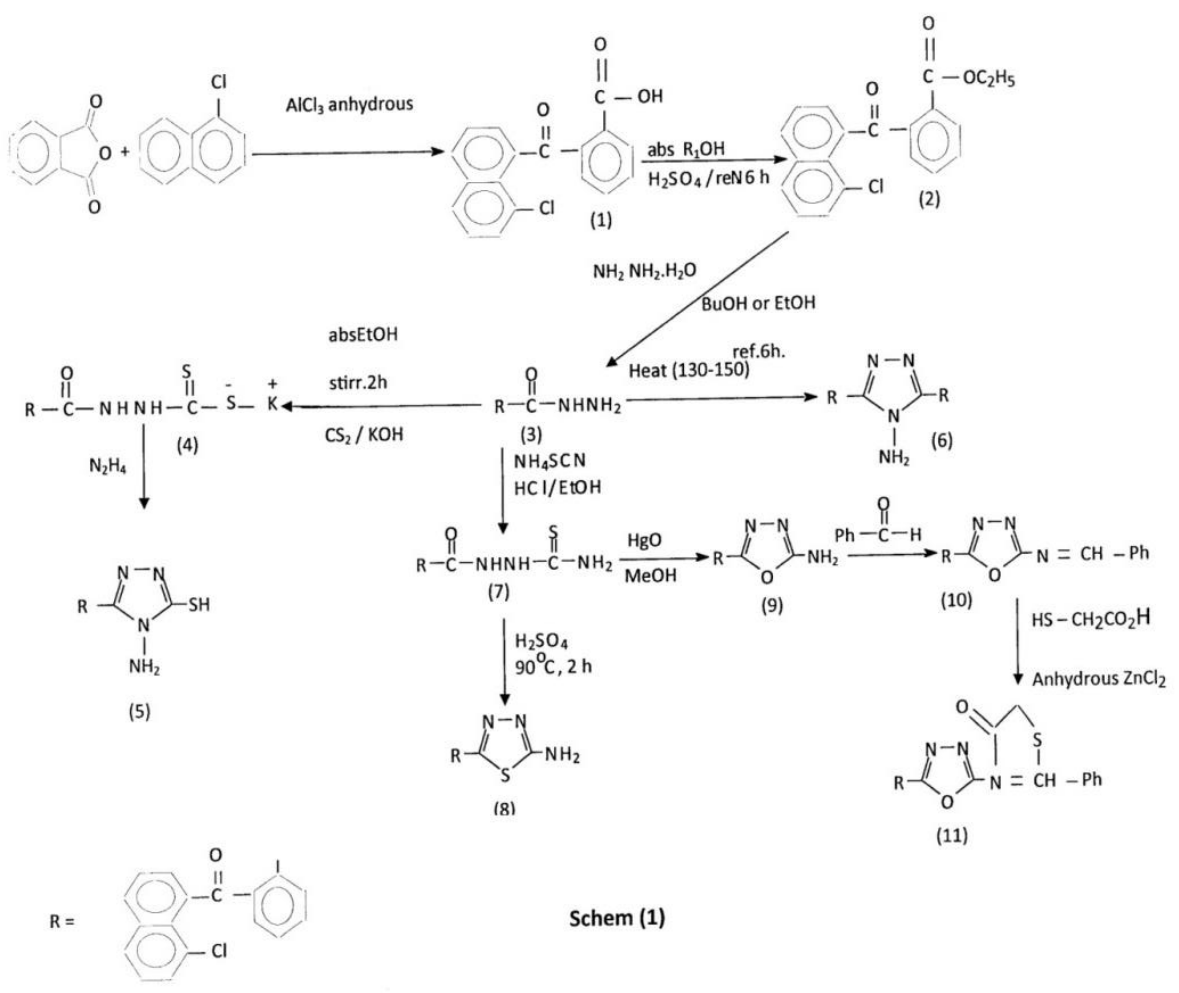



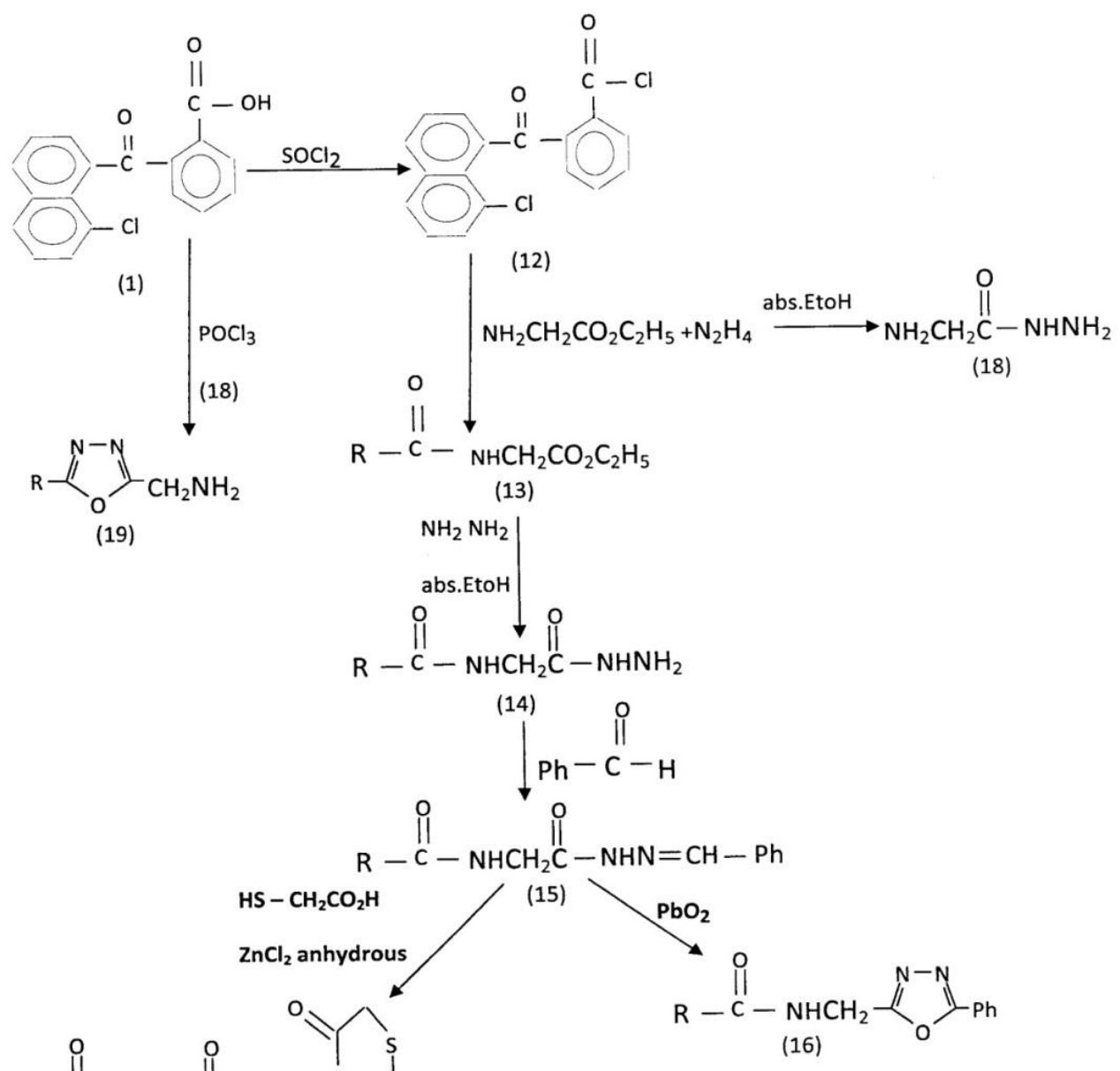<smiles>[R]C(=O)NCC(=O)NN1CCC1c1ccccc1S</smiles>

(17)

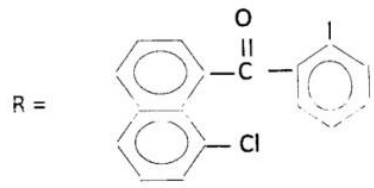

Schem (2)

\section{References}

1- Omar F A, Mahfouz N M and Rahman M A, Eur. J. Med Chem.Vol.3,p.1819825 (1996),

2- Narayana B, Vijayaraj K K, Ashlatha B V and Kumari N S. Arch. Pharm. (Weinheim) 338, p. 373-377 (2005)

3- Amir M and Kumar S, Acta Pharm vol.57,p. 31-45(2007).

4- Gaonkar SL, Rai K M and Prabhuswamy B, Eur, J. Med Chem. 5- Vol 41 p, 841-846(2006)

5- Ali MA and Yar M S, Bioorg. Med. Chem.Lett.Vol.17,P3314-3316(2007). 
6- Zarghi A, Tabatabai S A, Faizi M. Ahadian A, Navabi P, Zanganeh V Zarghi and Shafiee A,Bioorg.Med. Chem. Lett.vol.15 p 1863-1865 (2005)

7- Tan T M, Chen Y, Kong K H, Bai J, Li Y,Lim S G, Ang TH and Lam Y, Antiviral Res.Vol.71,p. 7-14 (2006)

8- Amir M, Khan M S Y, zaman M S, Indian J Chem.,Vol. 43B, p 2189-2194 (2004).

9- Garoufalias S S P, Tani E, Todoulou O, Valiraki A P, Filippatos E, Clercq E D and Kourounakis P N,J Pharm Pharmacol., Vol.50, p 117-124( 1998)

10- HuiXP, zang CH, Wang Q and zhang Q, Indian J Chem., Vol 41B,2176-2179 (2002)

11- Tsukuda T, Shiratori Y, Watanade M H, Ontsuka K, Hattori M, Shirai N and Shimma, Bioorg Med Chem Lett., Vol. 8, p.1819-1824(1998)

12- Berk B, Aktay E, Yesilada E and Ertan M, Pharmazie,Vol. 56,p 613616(2001).

13- Holla B S, Poojary K N, Rao B S and Shivananda M K, Eur J Med Chem., Vol. 37, p. 511-517(2002).

14- Amir M, Alamkhan S and Drabo S, J. Indian Chem. Soc., Vol. 79, p.280( 2002).

15- Liu X H, Weng J Q, and Tan CX,J.Chem. Artic306361,Volume(2013)

16- Husain A. and Ajmal M.Acta Pharm. Vol.59,p.223-233 (2009)

17- Shandala M Y, Ayoub M T. and Noori M S. Raf. Jour. Sci., Vol.9, No.2 pp.34-39,(1998)

18- Salimon J, Salih N, Hameed A, Ibraheem H and Yousif EJ.App.Sci Research, 6(7), P.866-870 (2010).

19- Cansiz A, Koparir M and Demirdag A, Molecules Vol.9, p.204 -212,(2004)

20- Mohammad A O, M.Sc. Thesis, University of Mosul-Iraq (2001)

21- Wu M T, Heterocyclic J, Chem., Vol. 9,P.31(1972)

22- Pintilie O, Profirc L, Sunel V, Popa M and Pui A, Molecules,Vol 12, 103 113(2007).

23- Sharma R S and Bahel s C, J. ndian Chem.Soc., LIX,877,(1982)

24- Khanum S A, Shashikanth S,and Sudha B S, Heteroatom Chem. Vol 15, Number 1, (2004).

25- Abdul-Raheem L R, M.Sc. Thesis, University of Mosul-Iraq (2011).

26- Al Naimi K HY,Ph.D, University of Mosul Iraq (2000).

27- Sen-Gupta A K, and Hajela K, J. Indian Chem.Soc.,LVIII,690,(1981).

28- Al-jawharji Y Sh, M.Sc. Thesis, University of Mosul, Iraq, (2004).

Daoud K M, Ali A N and Ahmed A A, J. Edu. \&Sci.,Vol.(25), No(4). (2012). 